\title{
Spatial and Temporal Distribution of Polychlorinated Biphenyl Residues in Tropical Soils
}

\author{
John K. Bentum 1*, David K. Dodoo1, Peter K. Kwakye², David K. Essumang1, \\ George A. Adjei ${ }^{1}$ \\ ${ }^{1}$ Department of Chemistry, College of Agric \& Natural Sciences, University of Cape Coast, Cape Coast, Ghana \\ ${ }^{2}$ University College of Agriculture and Environmental Studies, Bunso, Eastern Region, Ghana \\ Email: ${ }^{\text {jbentun@ucc.edu.gh }}$
}

Received 5 February 2016; accepted 19 April 2016; published 22 April 2016

Copyright (C) 2016 by authors and Scientific Research Publishing Inc.

This work is licensed under the Creative Commons Attribution International License (CC BY). http://creativecommons.org/licenses/by/4.0/

c) (i) Open Access

\section{Abstract}

Polychlorinated biphenyls (PCBs) in tropical soil samples from the Central Region of Ghana, and their variation with the soil characteristics were assessed. The soil characteristics of seventy eight samples were first determined. The PCBs was extracted with (1:1) hexane:acetone mixture, and then the extract treated with concentrated $\mathrm{H}_{2} \mathrm{SO}_{4}, 5 \% \mathrm{KMnO}_{4}$ and copper. The extract was finally eluted from a silica gel column with hexane:dichloromethane $(97: 3 \mathrm{v} / \mathrm{v})$, and the PCBs analyzed using a gas chromatograph equipped with ${ }_{63} \mathrm{Ni}$ electron capture detector (GC-ECD model CP 3800). The composition of PCBs homologous in the soils followed the order: hexa-PCBs $(31.89 \%)>$ pentaPCBs $(23.98 \%)>$ tri-PCBs $(18.47 \%)>$ tetra-PCBs $(13.67 \%)>$ hepta-PCBs $(11.99 \%)$. The PCB congener profile in the study area was PCB $28>$ PCB $153>$ PCB $138>$ PCB $52>$ PCB $101>$ PCB $180>$ PCB 118. The mean concentration of the PCB congeners (dry matter basis) was PCB 28, $2.27 \pm$ 2.436; PCB 52, $1.84 \pm 2.27$; PCB 101, $2.17 \pm 2.52 \mu \mathrm{g} / \mathrm{kg}$; РCB 118, $0.83 \pm 0.89 \mu \mathrm{g} / \mathrm{kg} ;$ PCB 138, $0.99+$ $0.91 \mu \mathrm{g} / \mathrm{kg}$; PCB 153, $1.18 \pm 1.11 \mu \mathrm{g} / \mathrm{kg}$ and PCB $180,1.18 \pm 1.19 \mu \mathrm{g} / \mathrm{kg}$. The mean concentrations of $\Sigma$ PCBs were $9.15 \pm 0.52 \mu \mathrm{g} / \mathrm{kg}$ for the surface soils $(0-10 \mathrm{~cm}), 7.55 \pm 0.56 \mu \mathrm{g} / \mathrm{kg}$ and $7.82 \pm 0.55$ $\mu \mathrm{g} / \mathrm{kg}$ for the $10-20 \mathrm{~cm}$ and $20-30 \mathrm{~cm}$ sub-surface soils respectively. Significant but weak correlations were observed between PCBs and the soil $\mathrm{pH}$, moisture, and exchangeable base. The coefficient of determination for all significant correlations was between $6.6 \%$ and $18.75 \%$.

\section{Keywords}

Polychlorinated Biphenyls, Soil Properties, Principal Component Analysis, Contamination

\footnotetext{
${ }^{*}$ Corresponding author.
}

How to cite this paper: Bentum, J.K., Dodoo, D.K., Kwakye, P.K., Essumang, D.K. and Adjei, G.A. (2016) Spatial and Temporal Distribution of Polychlorinated Biphenyl Residues in Tropical Soils. Open Journal of Applied Sciences, 6, $234-247$. 


\section{Introduction}

Polychlorinated biphenyls (PCBs) are among the widespread pollutants in the global ecosystem and have been identified in the air, water, soils and sediments, fish, wildlife, plants, domestic animals, and human adipose tissue, blood and milk [1]-[6]. PCBs are naturally persistent, toxic and bioaccumulative in living organisms [7]-[9]. A large proportion of PCBs remains in transformers and capacitors in most developing countries [10] [11]. Sediments from the tropics have been found to contain relatively low concentrations of total PCBs.

The most polluted tropical site in the tropics has been found in India, which had sediment concentrations up to $2330 \mu \mathrm{g} / \mathrm{g} \mathrm{dw}$ attributed to industrialization and pollution. Sediments from pristine areas were unquantifiable at levels below the detection limits [12]. It has been reported that surface sediments were from the highly developed areas of West Bengal, India, and found that the total PCB concentrations from ten sites averaged $750 \mathrm{ng} / \mathrm{g}$ $\mathrm{dw}$, with a maximum detection of $2330 \mathrm{ng} / \mathrm{g} \mathrm{dw}$, and the PCBs were dominated by congeners with four to six chlorines [13]. Large variation in total PCBs from sediments around Singapore, ranging from 1.4 to $329.6 \mathrm{ng} / \mathrm{g}$ $\mathrm{dw}$ (average $=73.9 \mathrm{ng} / \mathrm{g} \mathrm{dw}$ ) has been found [14]. Other literature reports indicate that in 2005, information on polychlorinated biphenyls (PCBs) in environmental media in Africa was limited [15]. High concentrations of PCBs have been found in some countries in West Africa, such as the Gambia and Ivory Coast and Ghana, and all along this coast. They also gathered samples from land-based stations (Gambia, Sierra Leone, Ivory Coast and Ghana), and used particle dispersion models to seek the possible sources of the contamination [16]. Illegal dumping of waste containing these compounds-old electrical waste such as capacitors and other PCB-containing products was the likely sources of the pollution.

Developing countries take large amounts of waste from Western nations and break them down or dispose of them, often with little regard for safety or pollution. High levels of PCBs are released through volatilization, as well as the storage and scrapping of old ships. Another probable source of the PCBs is one of the world's largest ships' graveyards, just in the south of Nouadhibou in Mauritania, off the West African coast, where hundreds of wrecks have been grounded in shallow water. This break-up probably releases PCBs [16]. Polychlorinated biphenyl (PCB) concentrations in air and soil have been measured by various research groups from around the world. The average soil concentrations (pg/g dry weight) for Sigma PCB at background sites were 7500 (47 97,000) for Europe, $4300(110$ - 25,000) for North America, 1400 (61 - 9500) for South America, 580 (120 2900) for Asia, 390 (94 - 620) for Africa, and 280 (140 - 540) for Australia [17]. In Ghana, PCB concentrations ranged between 0.357 and $20.721 \mathrm{mg} / \mathrm{kg}$ have been found in soils in the Electricity Company of Ghana compound in Accra.

Investigation of the soil profile of this site revealed very high levels of PCBs, between $82.3 \mathrm{mg} / \mathrm{kg}$ and 129.96 $\mathrm{mg} / \mathrm{kg}$. Analysis of underground water indicated that the levels of PCBs in the water were $0.059 \mathrm{mg} / \mathrm{L}$ and 0.071 $\mathrm{mg} / \mathrm{L}$, which were higher than the recommended level of $0.0094 \mathrm{mg} / \mathrm{L}$ [18]. PCBs have been detected in human breast milk and some environment samples in Ghana [19] [20]. Even though importation of PCB-containing transformers and capacitors for use in Ghana ceased in 1972, it has been established that 455 pre-1972 possible PCB-containing transformers could be found countrywide.

Multivariate analysis has been used to assess the source of the PCBs and heavy metals in the soils from the study sites in the central region of Ghana [21]. This paper is aimed at assessing the temporal and spatial distribution of PCBs in the tropical soils from the central region of Ghana, and the variation of the extracted PCB residues with the soil properties.

\section{Experimental}

\subsection{Study Area}

The study areas (Figure 1) [21], is along the coast of the Central region in the southern part of Ghana. Four of the study areas, districts/metropolis, Efutu-Awutu-Senya and Appam, Mfantiman, Cape Coast and KomendaEdna-Eguaful-Abrim are bounded on the south by the gulf of guinea. The fifth study area, Agona district, is bounded on the south by Efutu-Awutu-Senya district. The areas are predominantly urban and coastal in nature with a varied, high density housing stock, but also substantial areas of open space and with very few manufacturing industry.

\subsection{Sampling}

Seventy eight composite soil samples were collected from the immediate surroundings of Electricity Corporation 


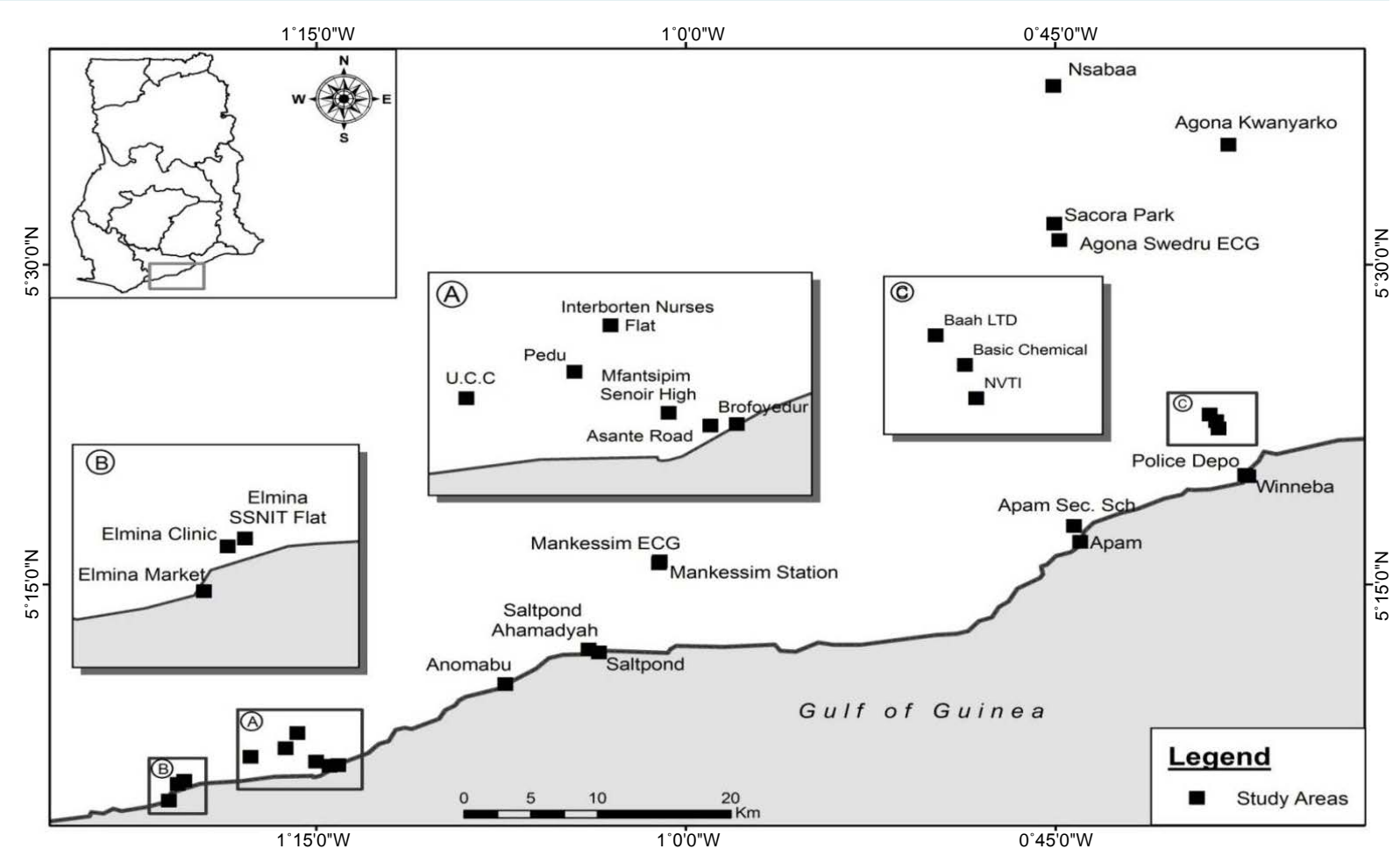

Figure 1. Map showing sampling sites in the central region [21].

Ghana (ECG) transformers at selected sites in the Central Region of Ghana at depth of $0-10 \mathrm{~cm}, 10-20 \mathrm{~cm}$ and $20-30 \mathrm{~cm}$. The samples were placed in labeled polythene bags and sent to the laboratory. They were air dried, and each sample was sieved using $250 \mu \mathrm{m}$ mesh sieve.

\subsection{Measurements of Soil Properties}

Standard procedure was used for the soils analysis. The following properties moisture, $\mathrm{pH}$, exchangeable acidity, exchangeable base and Effective Cation Exchange Capacity (ECEC), sand, silt, clay, moisture content and Soil Organic Matter [22]-[25].

\subsection{Analysis of PCBs}

For the PCBs analysis, a modified analytical procedures reported by Bentum in 2012 [26] were employed. Ten grams of air-dried soil was extracted with $100 \mathrm{ml}$ of hexane-acetone mixture $(1: 1 \mathrm{v} / \mathrm{v})$ for 16 hours using an automated soxhlet apparatus, and then concentrated to $10 \mathrm{ml}$. Hxane was added and concentrated to remove the acetone, after which it was dried with sodium sulphate and concentrated. $10 \mathrm{ml}$ of concentrated extract was transferred, with three $5 \mathrm{ml}$ hexane rinse of the flask into a separatory funnel for clean up. $10 \mathrm{ml}$ of the extract was cleanup with sulphuric acid (1+1), followed by clean up with $5 \mathrm{ml} 5 \%(\mathrm{w} / \mathrm{v}) \mathrm{KMNO}_{4}$ in order to decompose other organic compounds in the extract since PCBs are not affected by strong acids and oxidizing agents. Clean up with copper granules was to precipitate sulphur in the extract that might interfere with the gas chromatographic analysis; and finally with silica gel, and the column eluted with $100 \mathrm{ml}$ of hexane: dichloromethane $(97: 3 \mathrm{v} / \mathrm{v}) .1 \mathrm{ml}$ of the clean up extract was transferred into a pre cleaned $2 \mathrm{ml}$ vial with acetate ethyl resins and added to the vial to make the total volume $2 \mathrm{ml}$ and analyzed for PCBs using a gas chromatograph equipped with ${ }_{63} \mathrm{Ni}$ electron capture detector GC-ECD model CP 3800.

The capillary column used was VF $5 \mathrm{~ms} 30 \mathrm{~m} \times 0.25 \mathrm{~mm}$ id $\times 0.25 \mu \mathrm{m}$ film thickness. The GC conditions were as follows: injection point temperature: $270^{\circ} \mathrm{C}$; oven temperature programme: $70^{\circ} \mathrm{C}$ (hold $2 \mathrm{~min}$ ) to $180^{\circ} \mathrm{C}$ at a rate of $25^{\circ} \mathrm{C} / \mathrm{min}$ (hold $1 \mathrm{~min}$ ) to $300^{\circ} \mathrm{C}$ at a rate of $5^{\circ} \mathrm{C} / \mathrm{min}$. Temperature of detector was $300^{\circ} \mathrm{C}$; carrier gas-nitrogen at flow rate: $1.0 \mathrm{ml} / \mathrm{min}$; make-up gas flow rate: $29.0 \mathrm{ml} / \mathrm{min}$. The total runtime was $31.368 \mathrm{~min}$. The PCB congeners were identified qualitatively using their retention times, and their concentrations calculated 
on dry weight basis.

\subsection{Performance Validation and Reproducibility}

Two recovery study procedures were conducted for the performance validation (to assess the ability to achieved acceptable recovery) as well as the reproducibility of GC/ECD analysis. The first recovery study involved random spiking of duplicate soil samples with 0.02 ppm PCB mix standards, containing PCB\# 28, 52, 101, 118. 138, 153 and 180, before extraction. The recovery of $0.2 \mathrm{ppm}$ mix standards from the spiked duplicate soil samples was $89 \%$. The second recovery study involved the use of PCBs certified reference materials from the National Institute of Standards and Technology (NIST, USA). These samples were extracted and cleaned as described for the samples; the extracted samples were analyzed and the recoveries calculated. The percentage recovery of PCBs from the referenced standard reference material was $79 \%$. All the recoveries were within the acceptable criteria $(100 \% \pm 25 \%)$.

For the reproducibility, repeat analysis, of 0.02 ppm PCB mix standards containing PCB\# 28, 52, 101, 118. 138, 153 and 180 was used and the Relative Percent Difference (\%RPD) between duplicates calculated based on the peak areas (concentrations) of congeners with identical retention times. The \%RPD was within the acceptable range of $\pm 15 \%$.

\subsection{Statistical Analysis}

In order to explain the data generated, which are difficult to analyze and interpret because the complex relationships among the variables, the Kolmogorov-Smirnov test and Shapiro-Wilk test of normality, Pearson's regression and correlation, Multivariate analysis, Post Hoc test, principal component analysis (PCA) and cluster analysis (CA) were used to support the interpretation of complex data and extract meaningful information from the data [27]-[30]. Microsoft Excel 2010 and SPSS (version 16) were used for the calculations and statistical analysis.

\subsection{Multivariate Analysis}

Multivariate analysis, principal component analysis (PCA) and cluster analysis (CA) and correlation matrix were used in the study to provide a better insight and understanding of the dynamics of the PCBs in the top surface and subsurface soils, and source of variation in the data. PCA was applied on the logarithmic form of investigated PCB congeners data and Varimax with Kaiser Normalization rotation method used to maximize the sum of the variance of the factor coefficient, highly correlated variables or factors (with sum of squared loadings $>0.3$ ) were grouped into one component. The number of components indicated the total number of possible sources of variation in the data. For the cluster analysis hierarchical agglomerative clustering by the Ward's method was selected for sample classification because it possesses a small space distorting effect, uses more information on cluster contents than other methods, and has been proved to be an extremely powerful grouping mechanism [31]. The method was applied to normalized data using squared Euclidean distances as a measure of similarity [32].

\section{Result and Discussion}

\subsection{Results of Precision and Reproducibility of Analysis}

The recovery of $0.2 \mathrm{ppm}$ mix standards from the spiked duplicate soil samples indicated $89 \%$ recovery, which was within the $100 \% \pm 25 \%$ acceptable criteria. The precision of the analysis calculated as the relative percent difference (\%RPD) was $8 \%$ and was within the acceptable range of $\pm 15 \%$. The mean percentage recovery of PCB\# from the referenced standard reference material was $79 \%$.

\subsection{PCB Homologous}

The results of the analyses of soil PCBs from the Central Region are shown in Table 1. All the seven PCB congeners analyzed were detected in soils from all the study areas. Figure 2 shows the types and numbers of polychlorinated homologous detected in the samples from the various study areas. Generally, all these PCB homologous were found to be dominant in the Cape Coast Metropolis and least in the KEEA district. All the sites had 
Table 1. Mean of soil characteristics and polychlorinated biphenyls in soils from the central region of Ghana.

\begin{tabular}{cccccccccc}
\hline & & \multicolumn{7}{c}{ PCB Congener $(\mu \mathrm{g} / \mathrm{kg})$} \\
\hline Mean & 28 & 52 & 101 & 118 & 138 & 153 & 180 & $\sum$ PCB \\
Stdev & 2.26 & 1.84 & 2.17 & 0.83 & 0.95 & 1.14 & 1.23 & 7.99 \\
CV & 1.83 & 2.45 & 1.69 & 0.63 & 0.67 & 0.69 & 0.81 & 3.04 \\
Max & 81 & 133 & 83 & 79 & 71 & 63 & 65 & 38 & 12.94 \\
Min & 6.56 & 3.82 & 6.52 & 2.5 & 2.86 & 2.76 & 3.75 & nd & 1.32 \\
\hline
\end{tabular}

nd: not detected.

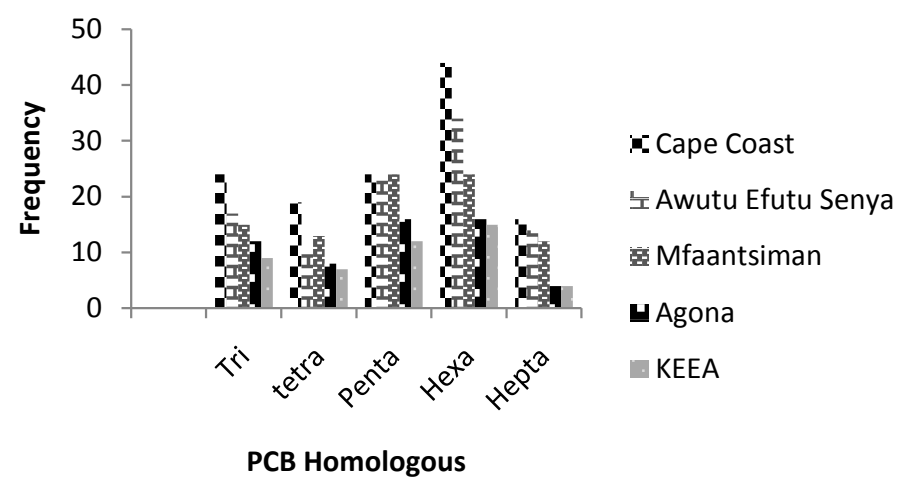

Figure 2. PCB homologous detected in soils from the study areas.

similar PCB composition.

The composition of PCB homologous in the soils was dominated by hexa-PCBs. The percentage composition of the homologous followed the order hexa-PCBs $(31.89 \%)>$ penta-PCBs $(23.98 \%)>$ tri-PCBs $(18.47 \%)>$ tetra-PCBs (13.67\%) > hepta-PCBs (11.99\%), followed by the penta-PCBs. Tetra-, penta-, and hexa-chlorinated biphenyls have been found as dominant species in some agricultural soils from Southern Jiangsu, China [33]. All the sites had similar PCB composition. This suggest the soils were probably contaminated from similar sources, most likely from transformer oils containing PCB Aroclor such as 1016, 1242, 1254 and 1260 [34].

\subsection{PCB Levels, Distribution and Congener Profile}

The concentration of the sum of the seven key PCBs (IUPAC No. PCB 28, PCB 52, PCB 101, PCB 118, PCB 138, PCB 153 and PCB 180) for 78 samples of soils from 26 sites are also shown (Figure 3). The concentration (mean $\pm \mathrm{CV}$ ) of PCBs in soils was $7.99 \pm 38 \mu \mathrm{g} / \mathrm{kg}$ and ranged from $1.32-12.94 \mu \mathrm{g} / \mathrm{kg}$. The highest concentrations of PCBs were found at two sites, Winneba (WPD) $12.72 \mu \mathrm{g} / \mathrm{kg}$ and Saltpond (SAH), $12.94 \mu \mathrm{g} / \mathrm{kg}$ and the least found in soils from Agona Nsaba (ANP) at the Agona district. The soils from SAH are sandy loams with higher organic carbon $0.39 \%$ and the other WPD is sandy soils, with lower organic carbon content $0.15 \%$. The observation is similar to those found in soils in the west coast of southern Sweden [35], where the highest concentrations were found at two sites with sandy soils, one with extremely high organic carbon.

Relatively high levels of PCBs were found in soil samples from the University of Cape Coast, Salt Pond and Winneba (WPD); and very low levels found in samples from Salt Pound ECG and Agona Nsaba. PCB concentrations in the soils showed a large variation between sampling-areas.

The highest concentrations were found at three sites; Winneba Police Depo (WPD), Apam Manfam (AM) and the University of Cape Coast (AU) with sandy soils, and one, WPD. Differences in PCB profiles were observed among districts, probably due to the combined number of transformers at the selected areas, effects of environmental conditions, and magnitude and age of the contamination, which determines the time available for volatilization and degradation, and differences in rainfall, which influence volatilization and deposition.

The spatial patterns of PCBs in the Central Region indicate that PCB concentrations $(\geq 4.62 \mu / \mathrm{kg})$ cover almost the entire costal area of the region. The mean $\sum$ PCB for the Agona district was $4.62 \pm 0.06 \mu \mathrm{g} / \mathrm{kg}$, lower than the overall regional average of $7.99 \pm 38 \mu \mathrm{g} / \mathrm{kg}$ (Figure 3). The mean $\sum$ PCB for the other areas were higher than the 


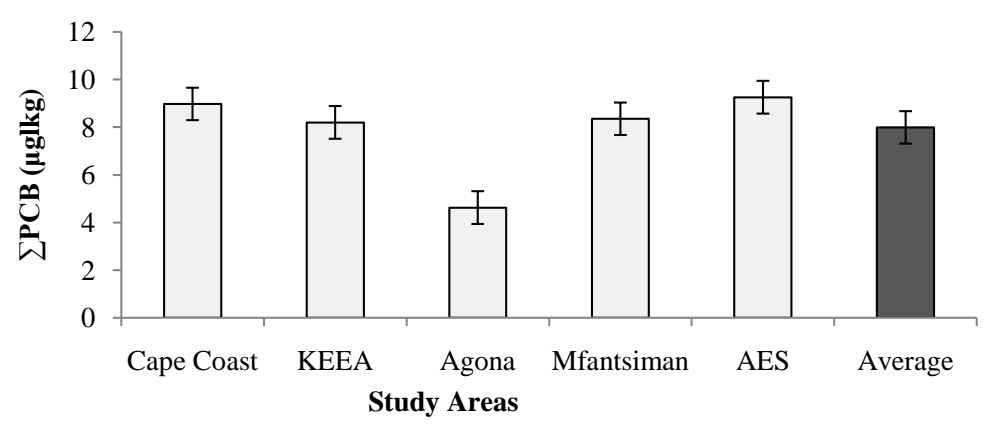

Figure 3. Mean concentrations of PCBs at the study areas.

regional average, and follow the order: Agona $(4.62 \pm 0.06 \mu \mathrm{g} / \mathrm{kg})<$ KEEA $(8.20 \pm 0.04 \mu \mathrm{g} / \mathrm{kg})<$ Cape Coast $(8.24 \pm 0.06 \mu \mathrm{g} / \mathrm{kg})<$ Awutu-Efutu Senya (AES) $(9.28 \pm 0.53 \mu \mathrm{g} / \mathrm{kg})<$ Mfantsiman (ASM) $(9.56 \pm 0.38 \mu \mathrm{g} / \mathrm{kg})$. The means and ranges of the congener concentration and $\sum$ PCB for $0-30 \mathrm{~cm}$ samples from the selected districts and metropolis (Table 2).

The concentration (mean $\pm \mathrm{CV}$ ) of PCB congeners found in the soils, $0-30 \mathrm{~cm}$, from all the five selected areas in the Central region (Table 2) were as follows: PCB-28, $2.26 \pm 81 \mu \mathrm{g} / \mathrm{g}$; PCB-52, $1.84 \pm 133 \mu \mathrm{g} / \mathrm{kg}$; PCB-101, $2.17 \pm 83 \mu \mathrm{g} / \mathrm{kg}$; PCB-118, $0.83 \pm 79 \mu \mathrm{g} / \mathrm{kg}$; PCB-138, $0.95 \pm 71 \mu \mathrm{g} / \mathrm{kg}$; PCB-153 $1.14 \pm 63 \mu \mathrm{g} / \mathrm{kg}$ and PCB-180 $1.23 \pm 65 \mu \mathrm{g} / \mathrm{kg}$. There were variation in the levels of the congeners, PCB-52 showed the greatest variation of $123 \%$ and $\mathrm{PCB}-153$ the least $63 \%$. The variation, as revealed by the percent relative standard deviation, increase in the order PCB-153 < PCB-180 < PCB-138, PCB-118 < PCB-28 < PCB-101 < PCB-52. Figure 4 shows the distribution profile of the PCB congeners in soils from the study areas.

The highest concentrations of PCB 28, 153 and 180 were found in the Awutu-Eufutu-Senya district (AES) (Figure 4); PCB 101, 118 and 138 were found highest at Elmina in the Komenda-Edna-Eguaful-Abrem district (KEEA); and PCB 52 found highest at Anomabo (ANO), Salt-Pond, Mankesim area in the Mfants man district (ASM).

The presence of PCBs in the soils is not strange as observed much higher concentrations of PCBs in soil at different sites in an assessment of Persistence Organic Pollutants (POPs) contamination sites in the transformer servicing center of the Electricity Company of Ghana in Accra [36]. The levels of PCBs ( $\mathrm{PCB})$ in the study areas were about one-thousandth of the levels found in soils in the transformer servicing center of the Electricity Company of Ghana in Accra, which were between $0.357 \mathrm{mg} / \mathrm{kg}$ and $20.721 \mathrm{mg} / \mathrm{kg}$. The levels of PBCs contamination in the soils studied were much lower than the recommended limits of $25 \mathrm{mg} / \mathrm{kg}$ and $33 \mathrm{mg} / \mathrm{kg}$ set by the Canadian Soil guide [37], and the US EPA [38], respectively. The levels were comparable to levels detected in soils in Linfen city, China [39], lower than those found in soils elsewhere in Bahrain [40], Moscow region [41], Switzerland [42], Belarus [43], New York [44], Shanghai [45], but higher than those found in Poland [46].

\subsection{Vertical Distribution of PCBs in the Soils}

The box-and-whisker plots of total PCBs ( $\Sigma \mathrm{PCB})$ in the top and sub-surface soils from all sampling sites (Figure 5) were examined. The mean levels of $\Sigma$ PCBs (based on dry weight) was $9.15 \pm 0.53 \mu \mathrm{g} / \mathrm{kg}$ for the top surface soils and $7.55 \pm 0.56 \mu \mathrm{g} / \mathrm{kg}$ and $7.82 \pm 0.55 \mu \mathrm{g} / \mathrm{kg}$ for the $10-20 \mathrm{~cm}$ and $20-30 \mathrm{~cm}$ subsurface soils respectively. The box plots for the PCBs relates to the levels of PCB contamination of the soils. In general the surface soils, $0-10 \mathrm{~cm}$, had the highest levels of PCBs ( $\mathrm{PCB}$ ), suggesting that the topmost soils are the most contaminated, and the $10-20 \mathrm{~cm}$ subsurface soils the least. Figure 6 show the levels and the distributions of PCBs in the different depth of the soils at the sampling sites.

\subsection{Relationship between soil PCB Concentration and Soils Parameters}

Regression analysis among the seven congeners revealed that only PCB 138 and 153 correlated significantly at the $5 \%$ level of significance. However, the correlation was weak $(r=0.30, p=0.5)$. Regression analyses revealed some significant relationships between the soil characteristics and the PCB content of the soils. The coefficient of determination, which is an expressed variation in the PCB levels due to variation in the soil characteristics was determined by squaring the correlation coefficient, and multiplying by 100 . It gave an indication 
Table 2. Means concentration PCB congeners and $\sum$ PCB for 0 - $30 \mathrm{~cm}$ soil samples.

\begin{tabular}{cccccccccccc}
\hline & & \multicolumn{9}{c}{ Mean PCB Congeners $(\mu \mathrm{g} / \mathrm{kg})$} & \multicolumn{3}{c}{$\sum \mathrm{PCB}(\mu \mathrm{g} / \mathrm{kg})$} \\
\cline { 3 - 11 } Sampling Area & (n) & 28 & 52 & 101 & 118 & 138 & 153 & 180 & Mean & range \\
\hline Cape Coast & 24 & 2.16 & 1.79 & 2.53 & 0.83 & 1.12 & 1.22 & 1.27 & $8.24 \pm 0.01$ & $3.58-12.21$ \\
KEEA & 9 & 1.99 & 1.22 & 2.68 & 1.62 & 1.49 & 0.64 & 0.56 & $8.20 \pm 0.04$ & $6.81-9.50$ \\
AES & 18 & 3.05 & 1.67 & 2.49 & 0.8 & 0.94 & 1.45 & 1.57 & $9.28 \pm 0.53$ & $4.46-12.72$ \\
ASM & 15 & 2.68 & 2.48 & 1.65 & 0.64 & 0.86 & 1.35 & 1.47 & $9.56 \pm 0.38$ & $3.22-12.94$ \\
Agona & 12 & 1.06 & 1.72 & 1.56 & 0.664 & 0.411 & 0.50 & 0.72 & $4.62 \pm 0.06$ & $1,32-6.97$ \\
\hline
\end{tabular}

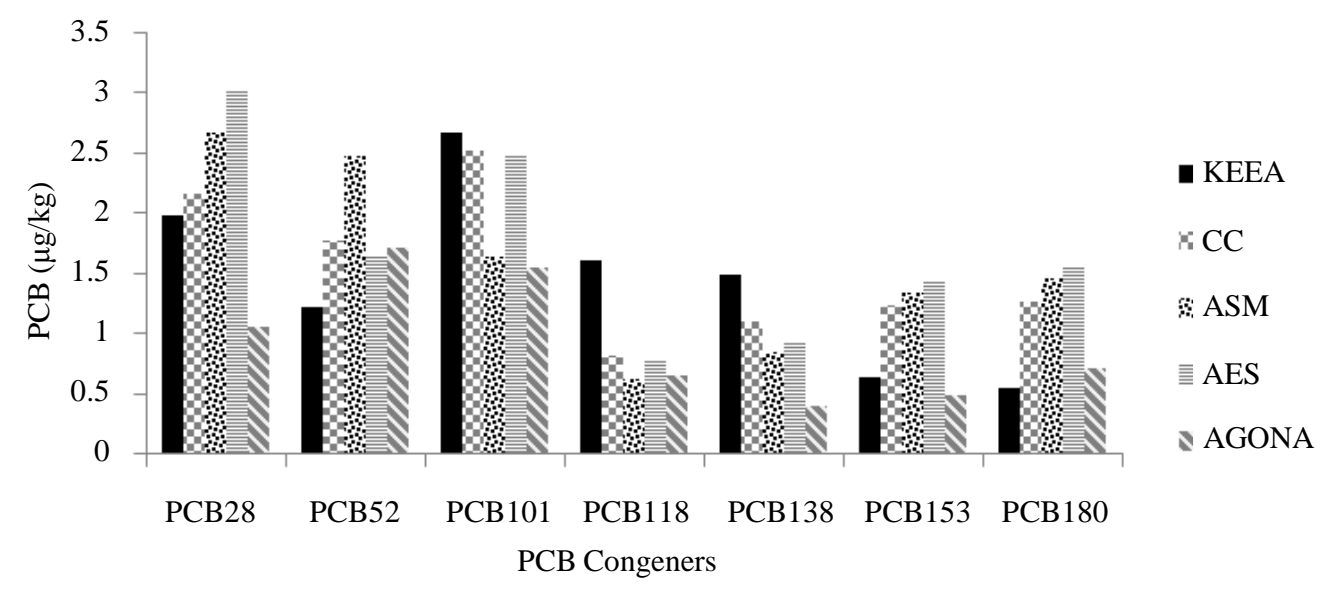

Figure 4. Mean concentration of PCB congeners in soils from the study sites.

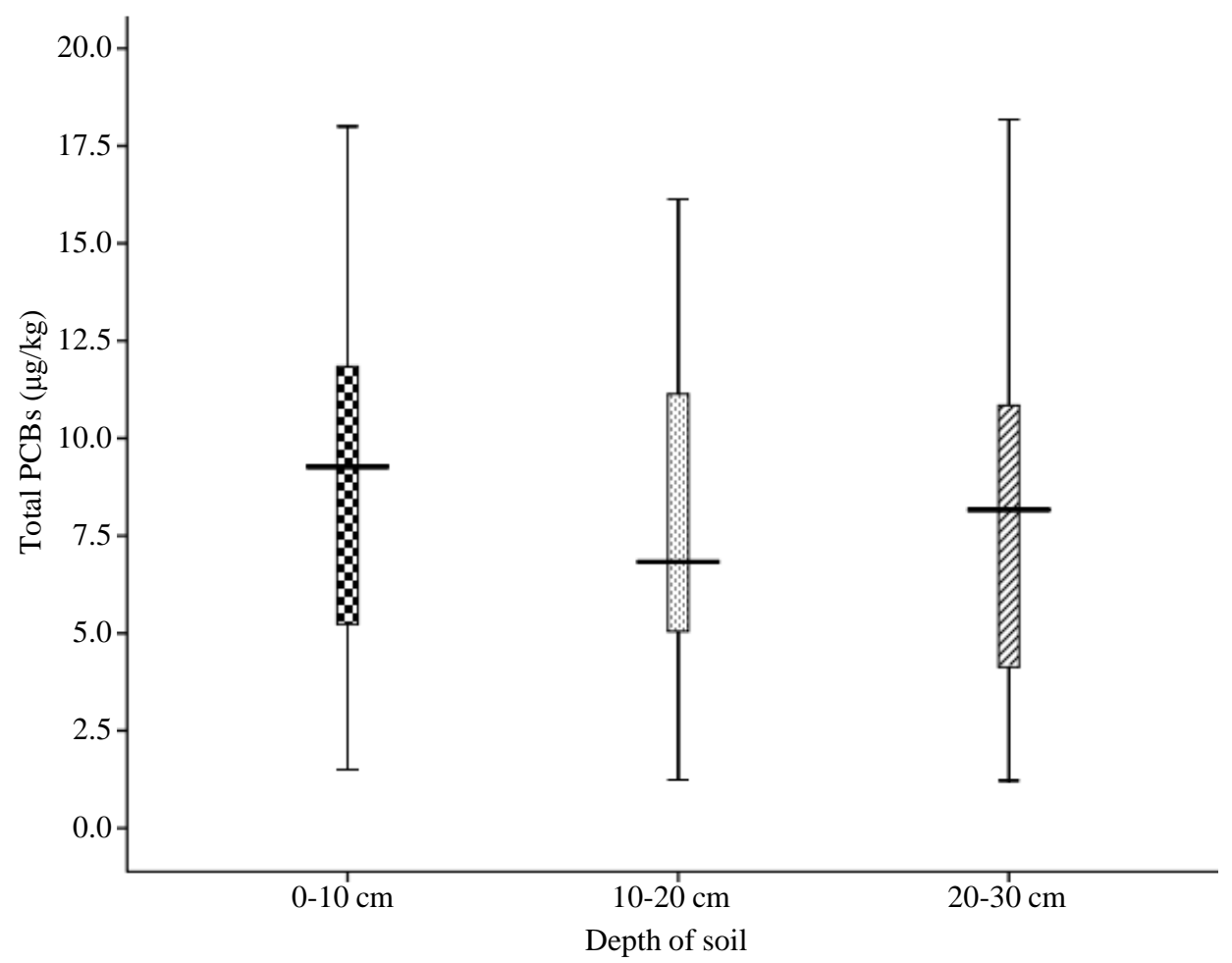

Figure 5. Box-and-whisker plots of $\Sigma$ PCB in top surface and subsurface soils. 


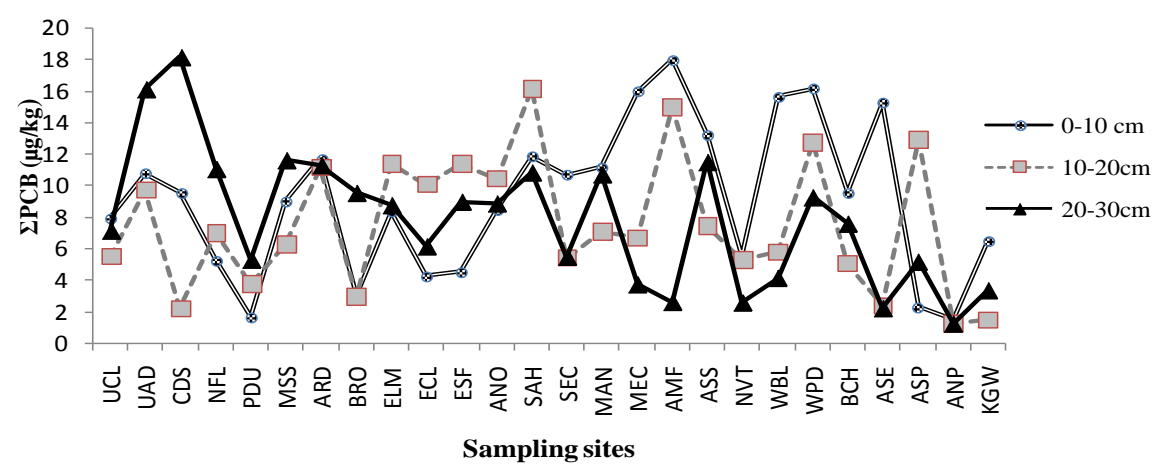

Figure 6. Profiles of PCBs at different depth of topsoils.

of the contribution of the characteristics to the varied levels of PCB residue. The characteristics of the soils (Table 3) indicate $\mathrm{pH}$ range of 6.07 - 7.4. The soils were characterized by relatively low organic carbon (organic matter) low moisture, low effective cation exchange capacity (ECEC) and high sand content. The moisture contents showed the greatest variation, $78 \%$ and $\mathrm{pH}$ the least, $7 \%$.

The $\mathrm{pH}$ of the surface soils correlated positively with PCBs content in the $10-20 \mathrm{~cm}$ sub-surface soils with $\mathrm{r}$ $=0.535(\mathrm{p}<0.01)$, but the correlations between $\mathrm{pH}$ and PCBs content in the $0-10 \mathrm{~cm}$ and $20-30 \mathrm{~cm}$ sub-surface soils were not significant. The PCB\# 138 and 180 correlated positively with pH at the 0.01 confidence levels; and the respective coefficients values of were 0.257 and 0.346 . Even though $\mathrm{pH}$ does not have direct effect on the degradation of PCBs, the coefficient of determination or explained variation as a percentage of total variation in the levels of PCB\# 138 and 180 in the soils that are accounted for by the variations in the soil $\mathrm{pH}$, were respectively $6.6 \%$ and $12.47 \%$.

With moisture content, a significant negative correlation was observed between the moisture and PCBs in the $20-30 \mathrm{~cm}$ sub-surface soils at 0.05 level, $\mathrm{r}=-0.414$. The coefficient of determination is $17.14 \%$. The soil organic carbon (organic matter) content showed only a weak correlation with the PCBs. However, the correlation was not significant.

Weak and insignificant correlation was between organic carbon and the PCBs. Similar observation has been reported [47]. The weak and statistically insignificant correlation observed between the PCBs and the soil organic carbon (organic matter) at the study sites might be due to decreased in sorption strength of the PCBs onto the soil organic matter with increasing residence time of the compound in soil, and the higher temperature of the prevailing tropical environment compared to the temperate region, resulting in desorption of the PCBs. The desorbed PCBs might have been co-evaporated with water, or volatilized from the soils. Sorption of organic compounds such as mono-ortho-polychlorinated biphenyls (PCBs) in soils and sediment in the temperate regions has been reported to be higher than could be anticipated based on the compounds' hydrophobicities [48]-[51]. Other soil properties, besides organic carbon (organic matter) might have been responsible for adsorption [52].

A significant negative correlation was observed between the exchangeable bases and the PCBs in the top surface and $10-20 \mathrm{~cm}$ sub-surface soils with respective correlation coefficients $r=-0.394$ and $(r=-0.433, p<$ 0.05 ). Thus the exchangeable bases accounts for $15.6 \%$ and $18.75 \%$ of the variations in PCBs in the top surface and 10 - $20 \mathrm{~cm}$ sub-surface soils respectively. PCB 101 correlated with exchangeable base $(\mathrm{r}=0.299, \mathrm{p}<0.05)$; with coefficient of determination of $8.9 \%$. Only, PCB 118, the mono-ortho-polychlorinated biphenyls in the PCB indicator used, correlated significantly with the exchangeable acidity, with $r=0.367(p<0.05)$. The coefficient of determination was $13.5 \%$.

The positive correlation is an indication that these PCBs were from the similar sources, probably Aroclor 1254 and 1260, which contain PCB 138, 153 and 180 [34] [53]. Even though the three PCB congeners are suspected to be from the similar source, no significant correlation was observed between PCB 180 and any of the other two. This could be due the degradation of PCB 180 (2, 2', 3, 4, 4', 5, 5' heptachlorobiphenyl) via removal of mata-chlorine from single chlorobiphenyl group to give either PCB 138 (22'344'5' hexachlorobiphenyl) or PCB 153 (22'44'55' hexachlorobiphenyl) as has been reported [54].

\subsection{Multivariate Analysis and Patterns in Soil PCB Congeners Distribution}

Kolmogorov-Smirnov test and Shapiro-Wilk test of normality data at 0.05 significance level showed that the 
three sets of PCB data were normally distributed and come from the same population. The F-statistic of the Analysis of variance (ANOVA) results showed that there were significant differences between the three sets ( 0 $10,10-20$ and $20-30 \mathrm{~cm})$ of soil PCB data at 0.05 level $(\mathrm{F}=0.975, \mathrm{df}=2$, p-value $=0.382$ ). Multiple comparisons among the three sets (Post Hoc test) performed in order to assess whether the variation as revealed by ANOVA was significantly high, showed that the variation was the highest for the $0-10 \mathrm{~cm}$ top surface soils with mean $\Sigma$ PCBs $(9.15 \pm 0.53 \mu \mathrm{g} / \mathrm{kg})$.

The results of the principal component analysis are shown in Tables 4-6. PCB congeners that showed moderate to high factor loading the values in bold. Three (3) principal components (PCs) with eigenvalues greater than one (1) were extracted. Three components identified for the surface soil (0 - $10 \mathrm{~cm})$; three (3), and four (4) components were extracted for the10 - 20 and 20 - $30 \mathrm{~cm}$ subsurface soils respectively. Thus the initial dimension of the three sets of data are reduced to three (3), three (3) and four (4), which cumulatively accounted for $72.81 \%, 64.99 \%$ and $78.82 \%$ of the total variability in the original PCB data of the study area respectively. Among them, three groups A1, A2 and A3 were identified in the top soils (Table 4).

Table 3. Mean of soil characteristics and polychlorinated biphenyls in soils from the central region of Ghana.

\begin{tabular}{ccccccccccc}
\hline & & \multicolumn{7}{c}{ Soil Characteristics } \\
\hline Mean & 7.4 & Moisture $\%$ & exA & exB & ECEC & OC \% & Sand \% & Silt \% & Clay \% \\
Stdev & 0.47 & 1.60 & 0.33 & 1.91 & 7.5 & 0.33 & 68.17 & 22.82 & 9.28 \\
CV & 7.0 & 78.0 & 35.0 & 74.0 & 51.0 & 46.0 & 19.0 & 46.0 & 52.0 \\
Max & 7.83 & 7.06 & 0.65 & 7.71 & 19.46 & 0.77 & 94 & 46.28 & 24 \\
Min & 6.07 & 0.31 & 0.23 & 0.78 & 3.24 & 0.15 & 29.72 & 2.78 & 3.2 \\
\hline
\end{tabular}

exA: exchangeable acid; exB: exchangeable base.

Table 4. Component matrix showing factor loadings for PCB congeners in $0-10 \mathrm{~cm}$ top surface soils.

\begin{tabular}{cccc}
\hline & & Component & A3 \\
\hline PCB 28 & A1 & A2 & -0.461 \\
PCB 52 & 0.726 & 0.253 & -0.443 \\
PCB 101 & -0.774 & -0.145 & 0.206 \\
PCB 118 & -0.029 & 0.759 & 0.68 \\
PCB 138 & -0.401 & -0.031 & 0.341 \\
PCB 153 & 0.691 & 0.14 & 0.527 \\
PCB 180 & 0.226 & -0.696 & 0.295 \\
\hline
\end{tabular}

Table 5. Component matrix showing factor loadings for PCB congeners in $10-20 \mathrm{~cm}$ sub-surface soils.

\begin{tabular}{cccc}
\hline & & Component & B3 \\
\hline PCB 28 & B1 & B2 & -0.234 \\
PCB 52 & 0.689 & 0.363 & 0.037 \\
PCB 101 & 0.651 & -0.408 & 0.434 \\
PCB 118 & 0.239 & 0.597 & 0.079 \\
PCB 138 & -0.065 & -0.711 & -0.242 \\
PCB 153 & 0.821 & 0.023 & -0.529 \\
PCB 180 & -0.43 & 0.451 & 0.866 \\
\hline
\end{tabular}

Significant correlations with factor loadings $>0.3$ have been made bold. 
Table 6. Component matrix showing Factor loadings for PCB congeners in 20 - 30 cm sub-surface soils.

\begin{tabular}{lcccc}
\hline & \multicolumn{3}{c}{ Component } & \\
\hline & C1 & C2 & C3 & -0.034 \\
PCB 28 & 0.365 & 0.836 & 0.209 & -0.203 \\
PCB 52 & -0.099 & 0.248 & 0.905 & 0.264 \\
PCB 101 & 0.445 & -0.524 & 0.137 & 0.828 \\
PCB 118 & 0.276 & 0.294 & -0.055 & -0.173 \\
PCB 138 & 0.808 & 0.302 & -0.081 & -0.485 \\
PCB 153 & 0.621 & -0.179 & 0.235 & -0.142 \\
PCB 180 & -0.613 & 0.428 & 0.477 & \\
\hline
\end{tabular}

Significant correlations with factor loadings $>0.3$ have been made bold.

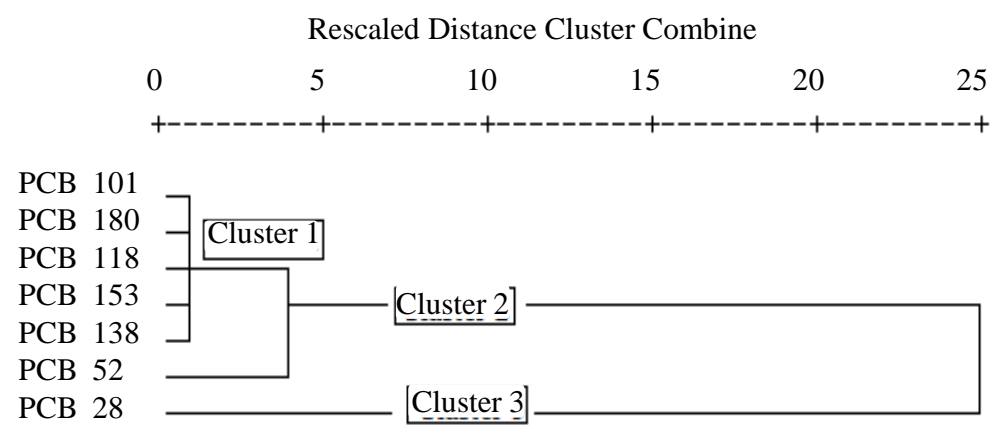

Figure 7. A dendrogram obtained by hierarchical clustering analysis for PCB congeners in surface soils $(0-10 \mathrm{~cm})$.

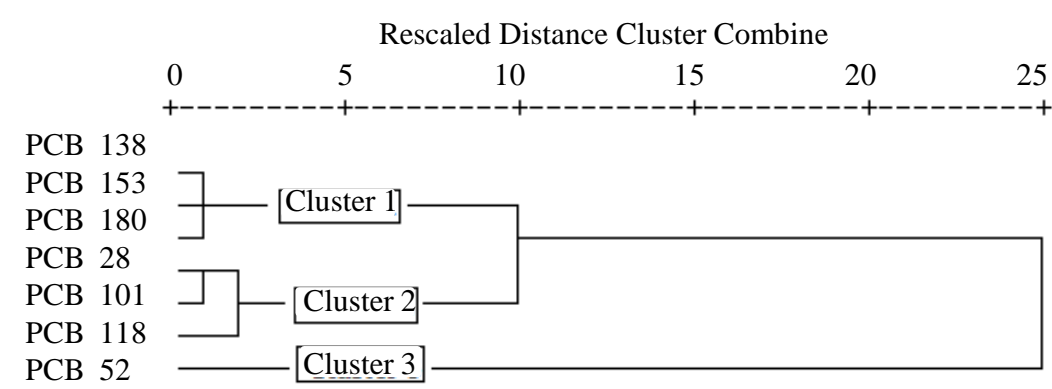

Figure 8. A dendrogram obtained by hierarchical clustering analysis for PCB congeners in sub-surface soils $(10-20 \mathrm{~cm})$.
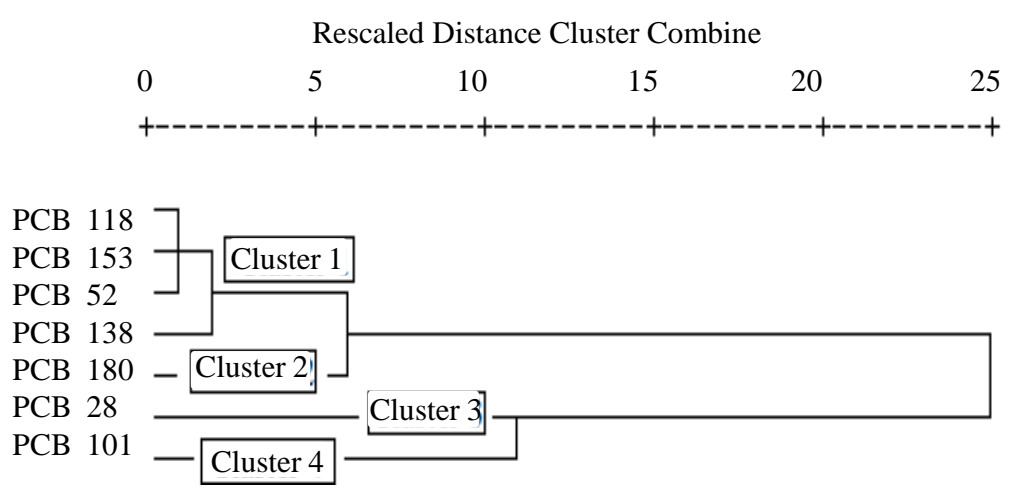

Figure 9. A dendrogram obtained by hierarchical clustering analysis for PCB congeners in sub-surface soils $(20-30 \mathrm{~cm})$. 
The first groups A1 was positively and moderately loaded with PCBs 28, and 138, but negatively loaded with PCB 52 and 118 respectively (A1: accounting for $25.76 \%$ of variance); the second group A2 was positively loaded with PCBs 101 and 180, and negatively loaded with 153. A2 accounted for 24.945\% variance and the third group A3, positively loaded with PCBs 118, 138, and 153; and negatively loaded with PCB28 and 52 into (A3: 22.11\% of variance). This imply in the topmost layer, the first, second and third principal components are strongly correlated with four, three, five of the original variables.

The subsurface soils (10 - $20 \mathrm{~cm}$ ), showed Three groupings (Table 5), with the first component, B1positively loaded with PCBs 28, 52 and, 138 and negatively loaded with PCB 153.B1, which account for $24.776 \%$ of variance. The second group B2, was positively loaded with PCBs 28, 101 and 153, and negatively loaded with PCB 52 and 118 into the accounting for $20.673 \%$ of variance. The third component B3 had positively loading PCBs 101 and 180 and negative loading of 153 in the grouped: accounting for $19.537 \%$ of variance. The first, second and third principal components of the $10-20 \mathrm{~cm}$ layer strongly correlated with four, four, and three of the original variables.

The subsurface soils $(20-30 \mathrm{~cm}$ ) had four components (Table 6), (C1: 26.165\% of variance) containing PCBs 28,101, moderately and highly loadings for PBC 153 and138 respectively, and negatively and moderately loading for PCB 180. The second component C2 (C2: 20.397\% of variance) containing 28, 138 and 180 and negative loadings for PCB 101 (C3: 16.768\% variance) and (C4: 15.489\% variance) are respectively characterized by PCBs 180 and 52, and PCBs 118 and 153. In the $20-30 \mathrm{~cm}$ layer, the four principal components significantly correlated with five, three, two and two of the original variables.

The results of PCA analysis suggest that soils with high Factor loadings values would tend to have a lot of the PCB congeners available. Whereas soil with small values would have very few of these congeners. Thus the dominant congeners in the $0-10 \mathrm{~cm}$ soils was PCB 180 with a factor loading of 0.799 . The $10-20 \mathrm{~cm}$ and $20-$ $30 \mathrm{~cm}$ soils were dominated respectively by PCB 180 with a factor loading 0.866 and PCB 52 with factor loading 0.905 .

Based on the information obtained from the PCA, hierarchical cluster analysis (CA) was performed on the PCB congeners with Ward's method and the squared Euclidean distance as similarity measured (Figures 7-9). Factors having strong correlation form cluster. The same number of groupings, three (3), three (3) and four (4) were obtained for the top surface $(0-10 \mathrm{~cm}), 10-20 \mathrm{~cm}$, and $20-30 \mathrm{~cm}$ subsurface soils respectively by the cluster analysis. For the $0-10 \mathrm{~cm}$ soils cluster 1 included PCB\# 101, 118, 138, 153 and 180; cluster 2 contained PCB\# 52 and cluster 3 contained PCB 28 (Figure 7). The subsurface soils $(10-20 \mathrm{~cm}$ ) is characterized by PCB\# 138, 153 and 180 in cluster1; PCB\# 28, 101 and 118 in cluser 2 and PCB 52 in cluster 3 (Figure 8). The first cluster of PCBs in the subsurface soils $(20$ - $30 \mathrm{~cm}$ ) included PCB\# 52, 118, 138 and 153; the second, contained PCB 180; the third and fourth were characterized by PCB\# 28 and 101 respectively (Figure 9).

\section{Conclusion}

The study revealed that among seven indicator PCBs which were found in soils samples from all the study areas, hexa-PCBs was the dominant of the PCB homologous. Generally the top surface soils had the highest concentrations of PCBs. The mean $\sum$ PCB $(0-30 \mathrm{~cm}$ soil) for the Agona district was $4.62 \pm 0.06 \mu \mathrm{g} / \mathrm{kg}$, lower than the overall regional average of $7.99 \pm 38 \mu \mathrm{g} / \mathrm{kg}$. It followed the order: Agona $(4.62 \pm 0.06 \mu \mathrm{g} / \mathrm{kg})<\mathrm{KEEA}(8.20 \pm$ $0.04 \mu \mathrm{g} / \mathrm{kg})<$ Cape Coast $(8.24 \pm 0.06 \mu \mathrm{g} / \mathrm{kg})<$ Awutu-Efutu Senya $(9.28 \pm 0.53 \mu \mathrm{g} / \mathrm{kg})<$ Mfantsiman $(9.56 \pm$ $0.38 \mu \mathrm{g} / \mathrm{kg}$ ). The variations in the concentrations of the congeners increased in the order: PCB-153 < PCB-180 < PCB-138, PCB-118 < PCB-28 < PCB-101 < PCB-52. Significant but weak correlations were observed between PCBs and the soil $\mathrm{pH}$, moisture and exchangeable base. Even though the soils examined were contaminated with PCBs, they were not polluted and can be classified as clean. However, the presences of these toxic compounds in the environment raise concerns because of their toxicity and potential to bio-accumulate.

\section{References}

[1] Jean-Pierre, C. (1988) Hazards, Decontamination, and Replacement of PCB: A Comprehensive Guide. Plenum Press, New York.

[2] WHO (1993) Polychlorinated Biphenyls and Terphenyls. Environmental Health Criteria, 2nd Edition, WHO, Geneva, 140.

[3] Fiedler, H., Hoff, H., Tolls, J., Mertens, C., Gruber, A. and Hutzinger, O. (1994) Environmental Fate of Organochlo- 
rines in the Aquatic Environment. Ecoinforma Press, Bayreuth, 199.

[4] Safe, S.H. (1994) Polychlorinated Biphenyls (PCBs) Environmental Impact, Biochemical and Toxic Responses, and Implications for Risk Assessment. Critical Reviews in Toxicology, 24, 87-149. http://dx.doi.org/10.3109/10408449409049308

[5] Davis, D.L. and Bradlow, H.L. (1995) Can Environmental Estrogen Cause Breast Cancer? Scientific American, 273, 166-172. http://dx.doi.org/10.1038/scientificamerican1095-166

[6] Berkaw, M. and Sowers, K.R. (1996) Anaerobic Orthodechlorination of Polychlorinated Biphenyls by Estuarine Sediments from Baltimore Harbor. Applied and Environmental Microbiology, 62, 2534-2539.

[7] Domingo, J.L., Agramunt, M.C., Nadal, M., Schuhmacher, M. and Corbella, J. (2002) Health Risk Assessment of PCDD/PCDF Exposure for the Population Living in the Vicinity of a Municipal Waste Incinerator. Archives of Environmental Contamination and Toxicology, 43, 461-465. http://dx.doi.org/10.1007/s00244-002-1280-6

[8] Erickson, M.D. (2001) Introduction: PCB Properties, Uses, Occurrence, and Regulatory History. In: Robertson, L.W. and Hansen, L.G., Eds., PCBs-Recent Advances in the Environmental Toxicology and Health Effects of PCBs, The University Press of Kentucky, Lexington, xi-xxx.

[9] Karlyn, B.K., Carlisle, J., Siegel, D. and Salinas, J. (2006) Health Concerns and Environmental Issues with PVC-Containing Building Materials in Green Buildings. Integrated Waste Management Board, California Environmental Protection Agency, USA, 11.

[10] Zhou, J.L., Maskaoui, K., Qiu, Y.W., Hong, H.S. and Wang, Z.D. (2001) Polychlorinated Biphenyl Congeners and Organochlorine Insecticides in the Water Column and Sediments of Daya Bay, China. Environmental Pollution, 13, 373-384. http://dx.doi.org/10.1016/S0269-7491(00)00180-9

[11] Nakata, H., Kawazoe, M., Arizono, K., Abe, S., Kitano, T., Shimada, H., et al. (2002) Organochlorine Pesticides and Polychlorinated Biphenyl Residues in Foodstuffs and Human Tissues from China: Status of Contamination, Historical Trend, and Human Dietary Exposure. Archives of Environmental Contamination and Toxicology, 43, 473-480. http://dx.doi.org/10.1007/s00244-002-1254-8

[12] Spongberg, A.L. and Witter, J.D. (2009) A Review of PCB Concentrations in Tropical Media, 1996-2007. Revista de Biología Tropical, 56, 1-9.

[13] Guzzela, L., Roscioli, C., Vigano, L., Saha, M., Sarkar, S.K. and Bhattacharya, A. (2005) Evaluation of the Concentration of HCH, DDT, HCB, PCB and PAH in the Sediments along the Lower Stretch of Hugli Estuary, West Bengal, Northeast India. Environment International, 31, 523-534. http://dx.doi.org/10.1016/j.envint.2004.10.014

[14] Wurl, O. and Obbard, J.P. (2005) Organochlorine Pesticides, Polychlorinated Biphenyls and Polybrominated Diphenyl Ethers in Singapore's Coastal Marine Sediments. Chemosphere, 58, 925-933. http://dx.doi.org/10.1016/j.chemosphere.2004.09.054

[15] Batterman, S., Chernyak, S., Gouden, Y., Hayes, J., Robins, T. and Chetty, S. (2009) PCBs in Air, Soil and Milk in Industrialized and Urban Areas of KwaZulu-Natal, South Africa. Environmental Pollution, 157, 654-663. http://dx.doi.org/10.1016/j.envpol.2008.08.015

[16] Gioia, R., Eckhardt, S., Breivik, K., Jaward, F., Prieto, A., Nizzeto, L. and Jones, C.K. (2011) Evidence for Major Emissions of PCBs in the West African Region. Environmental Science and Technology, 45, 1349-1355. http://dx.doi.org/10.1021/es1025239

[17] Li, Y.F., Harner, T., Liu, L., Zhang, Z., Ren, N.Q., Jia, H., Ma, J. and Sverko, E. (2010) Polychlorinated Biphenyls in Global Air and Surface Soil: Distributions, Air-Soil Exchange, and Fractionation Effect. Environmental Science and Technology, 44, 2784-2790. http://dx.doi.org/10.1021/es901871e

[18] United Nations Industrial Development Organization (UNIDO) (2012) Site Investigation Case Study: Ghana. Persistent Organic Pollutants: Contaminated Site Investigation and Management Toolkit. UNIDO, 127-164.

[19] Asante, K.A., Adu-Kumi, S., Nakahiro, K., Takahashi, S., Isobe, T. and Sudaryanto, A. (2011) Human Exposure to PCBs, PBDEs and HBCDs in Ghana: Temporal Variation, Sources of Exposure and Estimation of Daily Intakes by Infants. Environment International, 37, 921-928. http://dx.doi.org/10.1016/j.envint.2011.03.011

[20] Otchere, F.A. (2005) Organochlorines (PCBs and Pesticides) in the Bivalves Anadara (Senilis) Senilis, Crassostreatulipa and Pernaperna from the Lagoons of Ghana. Science of the Total Environment, 348, 102-114. http://dx.doi.org/10.1016/j.scitotenv.2004.12.069

[21] Bentum, J.K., Dodoo, D.K. and Kwakye, P.K. (2012) A Accumulation of Metals and Polychlorinated Biphenyls (PCBs) in Soils around Electric Transformers in the Central Region of Ghana. Advances in Applied Science and Research, 3, 634-643.

[22] David, R.L. (1994) Soil Science: Methods and Applications. John Willey \& Sons, New York, 140-146.

[23] Rowell, D.L. (1994) Soil Science Methods and Applications. Longman Scientific and Technical, Harlow. 
[24] Kilmer, V.J. and Alexander, L.T. (1949) Methods of Making Mechanical Analysis of Soils. Soil Science, 68, 15-24. http://dx.doi.org/10.1097/00010694-194907000-00003

[25] Black, C.A. (1965) Methods of Soil Analysis. Part II, American Society of Agronomy Publishing No. 9, Madison.

[26] Bentum, J.K. (2012) Assessment of the Levels and Distribution of Polychlorinated Chlorinated Biphenyls in Soils in the Vicinity of Electric Transformers in the Central Region of Ghana. PhD Thesis, University of Cape Coast, Ghana. Unpublished Thesis.

[27] Vega, M., Pardo, R., Barrado, E. and Deban, L. (1998) Assessment of Seasonal and Polluting Effects on the Quality of River Water by Exploratory Data Analysis. Water Research, 32, 3581-3592. http://dx.doi.org/10.1016/S0043-1354(98)00138-9

[28] Jenerette, G.D., Lee, J.D., Waller, W. and Carlson, R.E. (2002) Multivariate Analysis of the Ecoregion Delineation for Aquatic Systems. Environmental Management, 29, 67-75. http://dx.doi.org/10.1007/s00267-001-0041-z

[29] Singh, K.P., Malik, A., Mohan, D. and Sinha, S. (2004) Multivariate Statistical Techniques for the Evaluation of Spatial and Temporal Variations in Water Quality of Gomti River (India)—A Case Study. Water Research, 38, 3980-3992. http://dx.doi.org/10.1016/j.watres.2004.06.011

[30] Singh, K.P., Malik, A. and Sinha, S. (2005) Water Quality Assessment and Apportionment of Pollution Sources of Gomti River (India) Using Multivariate Statistical Techniques-A Case Study. Analytica Chimica Acta, 538, 355-374. http://dx.doi.org/10.1016/j.aca.2005.02.006

[31] Willet, P. (1987) Similarity and Clustering in Chemical Information Systems. Research Studies Press, Letchworth.

[32] Massart, D.L. and Kaufman, L. (1983) The Interpretation of Analytical Chemical Data by the Use of Cluster Analysis. Wiley, New York.

[33] Zhang, J.Y., Qiu, L.M., He, J., Liao, Y. and Luo, Y.M. (2007) Occurrence and Congeners Specific of Polychlorinated Biphenyls in Agricultural Soils from Southern Jiangsu, China. Journal of Environmental Sciences, 19, 338-342. http://dx.doi.org/10.1016/S1001-0742(07)60055-2

[34] US Environmental Protection Agency (USEPA) (2007) Standard Method 8082A-37.

[35] Backe, C., Cousins, I.T. and Larsson, P. (2004) PCB in Soils and Estimated Soil-Air Exchange Fluxes of Selected PCB Congeners in the South of Sweden. Environmental Pollution, 128, 59-72. http://dx.doi.org/10.1016/j.envpol.2003.08.038

[36] Centeno, C. (2010) POPs Contaminated Sites Assessment in Ghana Using the United Nations Industrial Development Organization (UNIDO) Toolkit. Contaminated Sites Conference 2010, Bratisalva, June. UNIDO. www.unido.org

[37] Canadian Council of Ministers of the Environment (CCME) (1999) Canadian Soil Quality Guidelines for the Protection of Environment and Human Health: Polychlorinated Biphenyls (Total). Canadian Environmental Quality Guidelines, Canadian Council of Ministers of Environment, Winnipeg.

[38] USEPA (1996) USEPA Method 8000B. US Environmental Protection Agency (USEPA), 41.

[39] Fu, S., Cheng, H., Liu, Y., Zhang, L., Yang, Z., Li, K., Xia, X. and Xu, X. (2008) Polychlorinated Biphenyls Residues in Soil in Linfen, China. Bulletin of Environmental Contamination and Toxicology, 81, 594-598. http://dx.doi.org/10.1007/s00128-008-9552-0

[40] Al-Haddad, A., Madany, I.M. and Farha, J.A. (1993) Levels of PCBs and PAHs in Bahrain Soil. Environment International, 19, 277-284. http://dx.doi.org/10.1016/0160-4120(93)90088-Y

[41] Wolfgang, W., Krauss, M., Safrono, G., Fokin, A.D. and Kaupenjohann, M. (2006) Polychlorinated Biphenyls (PCBs) in Soils of the Moscow Region: Concentrations and Small-Scale Distribution along an Urban-Rural Transect. Environmental Pollution, 141, 327-335. http://dx.doi.org/10.1016/j.envpol.2005.08.038

[42] Zennegg, M., Kohler, M., Tremp, J., Seiler, C., Minder-Kohler, S. and Beck, M. (2006) Joint Sealants, an Overlooked Diffuse Source of Polychlorinated Biphenyls (PCB) Results of a Nationwide Study in Switzerland. Organohalogen Compounds, 66, 899-904.

[43] Kukharchyk, T.I., Kakareka, S.V., Khomich, V.S., Kurman, P.V. and Voropai, E.N. (2007) Polychlorinated Biphenyls in Soils of Belarus: Sources, Contamination Levels, and Problems of Study. Pochvovedenie, 5, 532-540. http://dx.doi.org/10.1134/s1064229307050031

[44] Herrick, R.F., Lefkowitz, D.J. and Weymouth, G.A. (2007) Soil Contamination from PCB-Containing Buildings. Environmental Health Perspectives, 115, 173-175. http://dx.doi.org/10.1289/ehp.9646

[45] Jiang, Y., Wang, X., Zhu, K., Wu, M., Sheng, G. and Fu, J. (2011) Polychlorinated Biphenyls Contamination in Urban Soil of Shanghai: Level, Compositional Profiles and Source Identification. Chemosphere, 83, 767-773.

[46] Lulek, J., Szafran, B. and Lasecka, E. (1999) Levels of Polychlorinated Biphenyls in Soil Samples from Some Former Soviet Army Bases in Poland in Persistent, Bioaccumulative, Toxic Chemicals. Symposia Papers Presented before the Division of Environmental Chemistry. In: Lipnick, R.L., Ed., American Chemical Society in Preprints of Extended Ab- 
stracts, Vol. 39, American Chemical Society, Washington DC, 160-162.

[47] Silviu-Laurentiu, B., Majid, M., Staffan, L. and Mats, T. (2014) Leachability and Desorption of PCBs from Soil and Their Dependency on pH and Dissolved Organic Matter. Science of the Total Environment, 499, 220-227.

[48] Ayris, S. and Harrad, S. (1999) The Fate and Persistence of Polychlorinated Biphenyls in Soil. Journal of Environmental Monitoring, 1, 395-401. http://dx.doi.org/10.1039/a903017d

[49] Ahmad, R., Kookana, R.S., Alston, A.M. and Skjemstad, J.O. (2001) The Nature of Soil Organicmatter Affects Sorption of Pesticides: 1. Relationships with Carbon Chemistry as Determined by 13C CPMAS NMR Spectroscopy. Environmental Science and Technology, 35, 878-884. http://dx.doi.org/10.1021/es001446i

[50] Allen-King, R.M., Grathwohl, P. and Ball, W.P. (2002) New Modeling Paradigms for the Sorption of Hydrophobic Organic Chemicals to Heterogeneous Carbonaceous Matter in Soils, Sediments and Rocks. Advanced Water Resources, 25, 985-1016. http://dx.doi.org/10.1016/S0309-1708(02)00045-3

[51] Jonker, M.T.O. and Koelman, A.A. (2002) Sorption of Polycyclic Aromatic Hydrocarbons and Polychlorinated Biphenyls to Soot and Soot-Like Materials in the Aqueous Environment: Mechanistic Considerations. Environmental Science and Technology, 36, 3725-3734. http://dx.doi.org/10.1021/es020019x

[52] Wahid, P.A. and Sethunathan, N. (1979) Sorption-Desorptiono $\alpha$, and $\gamma$ Isomers of Hexachlorocyclohexanine Soils. Journal of Agricultural and Food Chemistry, 27, 1050-1053. http://dx.doi.org/10.1021/jf60225a020

[53] Caudle, W.M., Richardson, J.R., Delea, K.C., Guillot, T.S., Wang, M. and Pennell, K.D. (2006) Polychlorinatedbiphenyl-Induced Reduction of Dopamine Transporter Expression as a Precursor to Parkinson's Disease-Associated Dopamine Toxicity. Toxicological Sciences, 92, 490-499. http://dx.doi.org/10.1093/toxsci/kfl018

[54] Wu, Q., Bedard, D.L. and Wiegel, J. (1997) Temperature Determines the Pattern of Anaerobic Microbial Dechlorination of Aroclor 1260 Primed by 2,3,4,6-Tetrachlorobiphenyl in Woods Pond Sediment. Applied and Environmental Microbiology, 63, 4818-4825. 